\title{
INTRODUCTION
}

Man's civilization is the sum of his constructive achievement, the substance of his well being, the key of his progress. Yet in the historical development of human culture, one of the most essential and determining factors has ever been education. Paradoxically, education is both a product and producer of civilization. Besides being the regenerative process whereby man transmits his culture, it is also the revitalizing means whereby he reforms it.

In the analysis of this fundamental cultural factor that we term education, as in all research in the social field, the study of genetic development is enlightening. Hence it is that the evolution of educational thought and practice has come to receive increasing attention.

Those who seriously study the history of Western pedagogy come to the inevitable conclusion that the Middle Ages are of fundamental importance. During the mediaeval millennium our education, like so much of the rest of our civilization, was conceived in its essential present-day lineaments. It is true that constituent elements were Greek, Roman, and early Christian in origin, yet it is also true that these received new form and life in the Middle Ages.

If we wish precisely to fix the birth of modern Western pedagogy, it may well be placed in the twelfth century. In that epoch, not only was the curriculum in grammar greatly broadened and deepened, but also logic, the science of rational investigation, was more enthusiastically and intensively cultivated and applied to various categories of human knowledge. As a result, in that and succeeding centuries, fertilization by the rational method continued to beget and improve theology, philosophy, philology, and finally the physical, biological, and social sciences, in a process that knows no end.

For the twelfth-century educational "renaissance," we fortunately possess a most excellent source. The Metalogicon of John of Salis- 
bury, completed in II59, is a defense of logic in its broad sense. This extraordinary treatise summarizes and argues convincingly on behalf of the thorough study of grammar and logic, including rhetoric, as then offered in the higher educational institutions of northern France. During the eight centuries that have since elapsed, this pedagogical classic has never been translated in its entirety. Meanwhile, however, John of Salisbury's parallel treatise on political theory, the Policraticus, together with many another mediaeval work of similar significance, has been made available to scholars in careful vernacular rendition. Yet it would be difficult to maintain that any of these treatises contains more important implications for the history of civilization than does the present one.

\section{JOHN OF SALISBURY}

The author of the Metalogicon was born, of humble origin, at Old Sarum (Salisbury), ${ }^{1}$ in southern England, between III $_{5}$ and I120. ${ }^{2}$ As a boy, John of Salisbury seems early to have manifested an above-average intellect and been marked as promising ecclesiastical timber. Accordingly, despite his lack of means, we soon find him "learning the Psalter" from a local priest. ${ }^{3}$ In quest of further learning, he crossed the Channel to France in $1136{ }^{4}$ There, in the stimulating cultural atmosphere of Paris and Chartres, he studied for most of twelve years under several of the most brilliant masters of his day. John was a disciple of such great teachers as Peter Abelard, ${ }^{5}$ Robert of Melun, later Bishop of Hereford, Thierry of Chartres, ${ }^{6}$

\footnotetext{
${ }^{1}$ Called at this time Saresberia or Severia, according to John of Salisbury (Policraticus, vi, I8; viii, 19); the antecedent of modern Salisbury. See Gleason White, The Cathedral Church of Salisbury . . a and a Brief History of the See of Sarum.

${ }^{2}$ The earlier date, IIIo, given for his birth by some writers, e.g., H. O. Taylor (Mediaeval Mind, II, 201), is not accepted by Poole and Webb. Indeed, it does not accord with John's own statement (Metalogicon, ii, ro) that he was but a youth ("adolescens admodum") when he went to Paris to study in 1136 .

${ }^{3}$ Policraticus, ii, 28.

"Most of the information concerning his student life comes from his Metalogicon (ii, I0; $\mathrm{i}, 5)$. (Hereafter cited as Met.)

${ }^{5}$ John refers (Met., ii, 10, 17 ff.) to Abelard as "the Peripatetic from Pallet." The great master was in his fifties when John attended his lectures as an eager student.

${ }^{6}$ Thierry first taught at Chartres, later at Paris, whence he returned to Chartres to become chancellor in Ir4 $\mathrm{I}$.
} 
William of Conches, ${ }^{7}$ Richard l'Evêque, ${ }^{8}$ Gilbert de la Porrée, ${ }^{9}$ and the English divine, Robert Pullen. ${ }^{10}$ With their help, he became thoroughly grounded in the literary and dialectical Trivium, and learned something of the mathematical and scientific Quadrivium. On the completion of his theological studies under Simon of Poissy, ${ }^{11}$ he was ordained to the priesthood, probably at the Abbey Moutier de la Celle. ${ }^{12}$

After half a dozen or more years of training and service with the papal court, ${ }^{13}$ John was recalled to his native England in 1154 to assume the important position of secretary to Theobald, Archbishop of Canterbury. This position had apparently come to him through the good offices of Bernard of Clairvaux..$^{14}$ As secretary to the primate of England, he served on many important diplomatic missions, and journeyed several times to Italy, as well as to France and about England. ${ }^{15}$ By 1 159, when he dispatched the Metalogicon, together with the Policraticus, to Henry II's chancellor, Thomas Becket, John was a kind of plenipotentiary vicar general or "alter ego" for the aged and ailing Archbishop Theobald. ${ }^{16}$ On the latter's death in II6I, John continued as secretary to the new archbishop, Thomas

\footnotetext{
${ }^{7}$ John studied grammar and philosophy with William for three years. He says that he learned much from "the most learned and inspiring grammarian since Bernard of Chartres."

${ }^{8}$ "Styled "l'Evêque" even before he became Bishop of Avranches in 1171 .

'John's master in logic and theology, he later became Bishop of Poitiers. See John of Salisbury, Historia Pontificalis, chap. I2.

${ }^{10}$ Eminent theologian, later a cardinal and papal chancellor. See R. L. Poole, "The Early Lives of Nicholas Breakespeare and Robert Pullen," in Essays in Mediaeval History Presented to Thomas Frederick Tout, pp. 61-64.

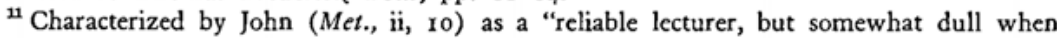
it comes to discussion."

${ }^{12}$ See on this, Maurice Demimuid (Jean de Salisbury, pp. 37-39), who bases his surmise on John's Ep. 85, and Peter of Celle's Epp., iv, 5, 7, 9; vii, 67; all in J. P. Migne, ed., Patrologiae cursus completus. Series latina, CXCIX and CCII. (Hereafter cited as Migne, P.L.)

${ }^{13}$ See R. L. Poole, "John of Salisbury at the Papal Court," in English Historical Review, XXXVIII (1923), 321-330, whose conclusions are based for the most part on the Historia Pontificalis.

${ }^{14}$ John was introduced to Archbishop Theobald by Bernard of Clairvaux at the Council of Rheims in 1148 (Hist. Pont., chaps. 1-15). The great Bernard also wrote a letter of recommendation on John's behalf to Theobald (Ep. 361, in Migne, P.L., CLXXXII, 562).

${ }^{15}$ John says (Met., iii, Prologue) that he crossed the Alps ten times. See also R. L. Poole, "Early Correspondence of John of Salisbury," in Proceedings of the British Academy, XI (I924), 5 I

${ }^{10}$ Met., Prologue; iv, 42.
} 
Becket, whose intimate counsellor he became. ${ }^{17}$ It is not unlikely that much of Becket's dramatic "conversion" and continuation of the Canterbury tradition of championship of Church liberties and privileges against royal usurpation are partly traceable to John's influence. Meanwhile John's activities, including the writing of his Policraticus, sive de nugis curialium et vestigiis philosopohorum libri VIII, which condoned the assassination of a tyrannical ruler, as well as his composition of a Life of St. Anselm, which lauded the sanctity of this spirited defender of ecclesiastical prerogatives against the English monarchy, brought down upon his head recurrent manifestations of the displeasure of King Henry II. Periods during which the learned cleric was forced to absent himself from England ensued. Nor was it long before John came to have Archbishop Thomas Becket as his companion in exile. When both returned to Canterbury during an ephemeral reconciliation of king and primate, John witnessed the murder of Becket by King Henry's knights in Canterbury Cathedral on December 29, II70. ${ }^{18}$ Six years later John, befriended by Louis VII, was elevated to the episcopate of Chartres. There he spent the remaining four years of his life, dying a revered bishop on October $25,1180 .{ }^{19}$

Although he was influential in the affairs of his day, John of Salisbury is especially admired by posterity for his writings. Particularly important are his Policraticus, or "Statesman's Book," ${ }^{20}$ his Metalogicon, or "Defense of the Trivium," and his Letters. John's Policraticus is ranked as a mediaeval classic on political theory. His Metalogicon occupies a similar position in the history of educational theory. $\mathrm{He}$ is also considered one of the leading letter writers of his day, and, according to some, of all time. Some three hundred and

\footnotetext{
${ }^{17}$ Cf. e.g., John's Epp., I13, 138, 142, in Migne, P.L., CXCIX, 98-99, 116-118, 122123; as well as Petrus Blesensis, Ep. 22, ibid., CCVII, 77-82.

${ }^{18}$ Cf. Willelmus Filius Stephani, Vita et passio sancti Thomae, in Migne, P.L., CXC, 183-184; and John's own account in his Vita sancti Thomae, ibid., CXC, 206-208.

${ }^{10} \mathrm{His}$ virtues and beneficial administration are warmly praised in "Elogium Johannis Saresberiensis episcopi Carnotensis," from the Necrologium Carnotense, in Gallia Christiana, VIII, II 48-II 49 .

${ }^{\infty}$ The Latin text has been critically edited by Clement C. J. Webb in two volumes (Oxford, 1909). It has been translated, in two parts, by John Dickinson as The Statesman's Book (New York, 1927), and by Joseph H. Pike, Frivolities of Courtiers and Footprints of Philosophers (Minneapolis, 1938).
} 
twenty-five of his Epistles are extant in printed form. ${ }^{21}$ His other works include two philosophic poems, each entitled Entheticus, the shorter being an introduction to his Policraticus, the longer a history of philosophy in 1,852 elegiac verses $;{ }^{22}$ his Historia Pontificalis, an account of the papacy from II 48 to ${ }_{1152} ;^{23}$ a Life of St. Anselm, Archbishop of Canterbury, ${ }^{24}$ and a Life of Thomas, Archbishop of Canterbury. ${ }^{25}$

\section{HISTORY OF THE TEXT}

Composed to defend the arts of verbal expression and reasoning comprised in the Trivium, the Metalogicon, on its completion in the fall of ${ }_{1159}{ }^{26}$ was sent, together with the Policraticus, to Chancellor Thomas Becket, to whom both of these works were addressed. ${ }^{27}$

The principal extant manuscripts of the Metalogicon are the Cantuariensis, De Bello, and S. Albani codices. In each of these the text of the Metalogicon is preceded by that of the Policraticus, as it was originally presented to Thomas Becket. The Cantuariensis (Canterbury or "C") codex, on parchment in folio, is in the Corpus Christi College Library at Cambridge University: MS Cod. 46, fols. $184^{\mathrm{r}}-239^{\mathrm{r}}$. It dates from the twelfth or, at the latest, the thirteenth century. There is little doubt that this was the original copy presented to Becket, for the title page shows the erasure of the follow-

${ }^{2}$ Mostly to be found in Migne, P.L., CXCIX, I-378.

2 The short Entheticus is prefaced to the Policraticus in the Webb edition; the long Entheticus is in Migne, P.L., CXCIX, 965-1004. The best edition of the long Entheticus is that of Christian Petersen (Hamburg, 1843 ).

${ }^{23}$ The best edition is that of Reginald Lane Poole (Oxford, 1927).

${ }^{24}$ Vita sancti Anselmi archiepiscopi Cantuariensis in Migne, P.L., CXCIX, I110-1140.

${ }^{2}$ Vita sancti Thomae Cantuariensis archiepiscopi et martyris, ibid., CXC, 195-203.

The Metalogicon must have been composed after the Policraticus, to which it alludes, and which had been completed in August or September, I159. When John wrote the final chapter, he already knew of the death of Pope Adrian IV, August 31, 1159, and the election of Cardinal Octavian as Antipope Victor IV, in the first week of September, although the news of the lifting of the siege of Toulouse at the close of the same month had not yet reached him. Cf. Webb, John of Salisbury, p. 19; and Poole, "Early Correspondence of John of Salisbury," Proceedings of the British Academy, XI (1924), 31-32, 36; as well as Met., iv, 42 .

${ }^{27}$ Met., Prologue, and iv, 42. 
ing words: "Sci. Thome archiepiscopi." ${ }^{28}$ It is interesting to note that even in this, presumably original copy, the scribe apparently made some mistakes. The De Bello (Battle Abbey or "B") codex, also on parchment in folio, is in the Bodleian Library of Oxford University: MS Lat. Misc., c.16, fols. $136^{\nabla}-170^{\nabla}$. Of the thirteenth, or at the latest, the early fourteenth century, it rarely disagrees with the Cantuariensis, except that it breaks off abruptly at Chapter 36 of the concluding book (Bk. IV), which comprises forty-two chapters. ${ }^{29} \mathrm{~A}$ notation on the first page indicates that the codex was given to Battle Abbey by Abbot Richard (+1235). The S. Albani (St. Alban's or "A") codex is in the British Museum: MS Reg. I3, $\mathrm{D}, \mathrm{IV}$, fols. $\mathrm{I}^{1} \mathrm{I}^{\mathrm{r}}-208^{\mathrm{r}}$. It is likewise on parchment in folio, and probably dates from the twelfth century. An inscription on the first page states that the manuscript was given to St. Alban's by Abbot Simon, who is known to have died in 1188 .

To date, the Latin text of the Metalogicon has been published in six printed editions. ${ }^{30}$ Three editions appeared in the seventeenth century: Paris, r6ro, Leyden, 1639, and Amsterdam, r664; all of them based on the text of a Cambridge University manuscript. ${ }^{31}$ Two editions were published in the nineteenth and one in the twentieth century. ${ }^{32}$ The last, the definitive edition, by Clement C. J. Webb, utilizes the principal codices, the "C," "B," and "A," and notes divergent readings in its critical apparatus. This excellent critical edition has been invaluable to the present translator.

Despite its six Latin editions and extensive use by historians, the Metalogicon has never before been translated in its entirety. Many

\footnotetext{
${ }^{28}$ See Montague Rhodes James, The Ancient Libraries of Canterbury and Dover, pp. xlii, 85, 158, 510; and The Sources of Archbishop Parker's Collection of Manuscripts at Corpus Christi College, pp. 5, 22.

${ }^{2}$ For a description of this manuscript, see Falconer Madan, Summary Catalogue of Western Manuscripts in the Bodleian Library at Oxford, VI, no. 32708 (p. 189).

${ }^{30}$ In the early printed editions the title Metalogicon was changed to Metalogicus; doubtless the modified ending was due to the influence of the Policraticus.

"Apparently the Cambridge Univ. Lib., MS Codex I, i-ii, 31. Sec Catalogue of MSS in the University Library at Cambridge, III, 400.

${ }^{80}$ In the nineteenth century: that of J. A. Giles: Ioannis Sarisberiensis...., Opera Omnia, nunc primum in unum colligit et cum codicibus manuscriptis contulit, 5 vols. (Oxford, 1848). The Metalogicus is in Vol. V, I-207. In the same century the Giles edition was reproduced without the critical notes in Migne, P.L., CXCIX. In the twentieth century appeared Clement C. J. Webb's edition: Ioannis Saresberiensis Episcopi Carnotensis, Metalogicon Libri IIII (Oxford, 1929).
} 
distinguished scholars have, however, included extensive translated extracts in their own works; for example, Carl Schaarschmidt, Reginald Lane Poole, Jules Alexandre Clerval, Charles Sears Baldwin, Barthélemy Hauréau, Etienne Gilson, Charles Homer Haskins, and Henry Osborn Taylor. ${ }^{33}$

\section{ANALYSIS OF THE METALOGICON}

The name "Metalogicon" is of Greek derivation, in accordance with a fad for Greek titles prevalent among twelfth-century writers. ${ }^{34}$ It is apparently a synthesis, original with John of Salisbury, of the two Greek words " $\mu \epsilon \tau \dot{\alpha}$ ": "about," "for," or "on behalf of,"

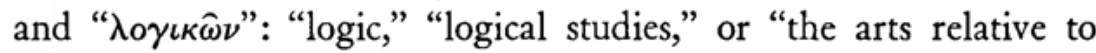
words and reasoning." The author informs us that his title means "a defense of," or "plea for" the studies of the Trivium. ${ }^{35} \mathrm{He}$ explains

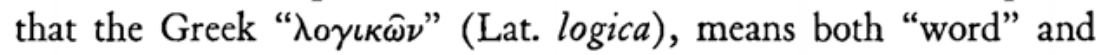
"reason," and that the term "logic" is here used in its broader sense: embracing not only the science of reasoning but also the arts and sciences of verbal expression.

The Metalogicon was composed to refute attacks made on the Trivium by a group whose spokesman John dubs "Cornificius," 36 after the detractor of Vergil and the liberal arts, who is mentioned by Donatus in his Life of Vergil. ${ }^{37}$ The work comprises four books, each divided into several chapters. Its contents may be analyzed as follows:

\section{General Prologue: Introduction}

Occasion, Purpose, and General Nature of the Work

\footnotetext{
${ }^{33}$ Schaarschmidt, Johannes Saresberiensis nach Leben und Studien, Schriften und Philosophie; Poole, Illustrations of the History of Mediaeval Thought ... ; Clerval, Les Écoles de Chartres au moyen-âge... ; Baldwin, Mediaeval Rhetoric and Poetic; Hauréau, Histoire de la philosophie scolastique; Gilson, La Philosophie au moyen-âge; Haskins, The Renaissance of the Twelfth Century; Taylor, Mediaeval Mind.

${ }^{34}$ Examples are St. Anselm's Monologium and Proslogium; Hugh of St. Victor's Didascalion; William of Champeaux's Dragmaticon.

${ }^{25}$ Met., Prologue.

${ }^{30}$ See Met., i, 1-3.

${ }^{37}$ Donatus, Vita Vergilii interpolata (cd. Brummer, pp. $30 \mathrm{ff}$.).
} 
Book I: The Trivium and Grammar

The Trivium: Unjustified Attacks on the Trivium; The

Nature, Utility, and Important Position of the Trivium

Among the Liberal Arts

Grammar: Its Nature, Content, and Utility, together with

How It Should be Taught and Studied

Chaps. I-I2

Chaps. $13-25$

Book II: Logic Proper: General Observations

The Origins, Nature, and Utility of Logic

Chaps. I-I5

How Logic Should Be Taught and Studied

Chaps. I6-19

Book III: Logic (cont.): Contents

Porphyry's Introduction

Chap. I

Aristotle's Categories

Chaps. 2-3

Aristotle's Interpretation

Chap. 4

Aristotle's Topics

Chaps. 5-10

Book IV: Logic: Contents (cont.), and Truth

Aristotle's Analytics, Prior and Posterior

Chaps. $\quad$ I -8

Cognition: Its Faculties, Operations, Object, and Basis

Chaps. 9-20

Conditional Reasoning

Chap. $2 \mathrm{r}$

Sophistical Reasoning and Aristotle's Sophistical Refutations

Chaps. 22-23

How Aristotle's Organon in General Is to be Taught and Studied

Chaps. 24-29

Truth, Cognitive, Affective, and Practical, as Man's Proper Goal

Chaps. $3^{0-42}$

A treatise on education, the Metalogicon urges thorough grounding in the arts relative to words (written as well as oral) and reasoning as these were then included in grammar and logic. Warning against various pedagogical aberrations, it advocates the use of sound psychological methods. It surveys the proper content of courses. "Grammar," a much broader subject in that day, embraced not only grammar as we know it, but also writing, spelling, composition, and "speech," together with general literature, including poetry and history. ${ }^{38}$ Logic, "the science of reasoning," ${ }^{39}$ John tells us, has truth as its object, and is best mastered by study (of the

${ }^{88}$ For grammar: Met., i, $13-25$

${ }^{⿰}$ For logic proper: Met., ii, iii, and iv, $1-8,21-29$. 
contents, if not always of the text) of Aristotle's Organon..$^{40}$ This discussion leads on to a survey of the psychology of cognition. ${ }^{41}$ The successive faculties of sensation and imagination, reason, and intuitive understanding; together with the ascending cognitive acts of opinion (from sensation and mental images), scientific knowledge, and wisdom; as well as the relation of faith and reasoning are all discussed. Truth: cognitive, affective, and practical, is upheld as the object of human reason and life. ${ }^{42}$

\section{SOURCES}

The list of known sources drawn on in composing the Metalogicon reads much as might the index for a condensed and combined edition of Greek and Roman classical authors, together with Patristic and mediaeval Christian writers (to the middle of the twelfth century). It is not always certain, of course, whether John had read the whole or part of the works in question, or merely extracts. Works of classical antiquity constitute John's principal sources. Although he knew some Greek, he apparently used his Greek sources in Latin translations. (The bibliography to the present translation lists works used by John.) Aristotle's Organon occupies first place. ${ }^{43}$ Plato's Timaeus, together with Chalcidius and Apuleius on Plato's doctrines, and Porphyry, Cicero, and Lucius Annaeus Seneca, the Younger, are further philosophical sources. On education in grammar, rhetoric, and the liberal arts, Quintilian, Marcus Annaeus Seneca, the Elder, Cicero and Martianus Capella are used; and on scientific subjects, Hippocrates, Pliny, Seneca the Younger, Palladius, and Vegetius. From the field of general literature John employs Terence, Catullus, Vergil, Horace, Ovid, Publilius Syrus, Valerius Maximus, Persius, Martial, Lucan, Statius, Juvenal, Suetonius, Gellius, Macrobius, and Pseudo-Plautus. Extensive use is made of the works of Church Fathers and subsequent mediaeval writers: Sts. Hilary of Poitiers, Jerome, Ambrose, Augustine, and Gregory the

\footnotetext{
${ }^{40}$ See Met., iii, 2-10; iv, 1-8, 2I-29.

"Discussed in Met., iv, 9-20.

${ }^{42}$ Met., iv, 30-42.

${ }^{43}$ Aristotle's Organon is discussed in Met., iii, 2-10; iv, 1-8, $21-29$.
} 
Great, together with Dionysius the Pseudo-Areopagite, Nemesius the Bishop, St. Fulgentius, Claudianus Mamertus, Boethius, Cassiodorous, St. Benedict, Alcuin, Angelomus of Luxeuil, Abelard, Gilbert de la Porée, Hugh of St. Victor, Adam du Petit Pont, William of Conches, and Bernard of Chartres. Works on grammar, history, science, and general topics include those of Sts. Augustine, Isidore of Seville, and Venerable Bede, Victorinus, Sidonius Apollinaris, Boethius, Cassiodorus, Remigius of Auxerre, Theodulus, Hugh of St. Victor, Tenred, and Geoffrey of Monmouth. Quotations from both the Old and New Testaments are liberally sprinkled throughout the Metalogicon. The Salernitanum Regimen sanitatis, the Digests from Justinian's Corpus Juris Civilis, and the Mythographi Tres are also used.

\section{LATIN OF THE METALOGICON}

Pronounced to be of the best and purest in the Middle Ages, still John of Salisbury's Latin displays features that mark it as of the twelfth century, when Latin was as yet alive and evolving. Not to mention the special new meanings attached to many words, there are several peculiarities in spelling. The single vowel $e$ is always used instead of the diphthongs $a$ and $\alpha ;^{44} i$ and $y$ are frequently interchanged, ${ }^{45}$ as also are $t$ and $c$; and $h$ is often omitted or, vice versa, added. John never uses $j$ for $i$ or $v$ for $u$, as do many later Latin writers. Numerous mediaeval Latin words are to be found in the text, such as "diacrisis," "subarrauerunt," "maneries," and "discolor": ${ }^{48}$ together with distinctly Christian terms, or words used in a distinctly Christian sense, such as "Christiane," "fidelibus," "ecclesiam," and "episcopus"; ${ }^{47}$ and Greek words transliterated into the Latin alphabet, such as "logos," "lecton," "lexis," and "idos," 48 and even provided with Latin endings, as "simplasim," "kirriadoxas," "paradoxas," "Fronesim," and "Alicie." ${ }^{49}$ Not only is John's

\footnotetext{
"As in cecum, estuantis, fedus, cherillus.

${ }^{45}$ As in ydolorum and hipoteseos.

${ }^{48}$ Cf. Met., i, 24; ii, Prol., 17; iii, ro.

${ }^{47}$ Cf. Met., iv, 42, 27; ii, ro.

${ }^{48}$ Met., i, 10; ii, 4, 17, 20.

${ }^{40}$ Met., iv, 10, 3I; ii, 3 .
} 
grammar in general flawless, but his style has been lauded as the most graceful of the twelfth century, and even of the Middle Ages. ${ }^{50}$ The text is enlivened by variety, antitheses, apt figures of speech, poetical quotations, classical references, and dashes of humor, which flavor its keen and penetrating thought. ${ }^{51}$

\section{HISTORICAL POSITION}

The Metalogicon has been termed by Charles Sears Baldwin "the cardinal treatise of mediaeval pedagogy." " 22 Whether or not Baldwin's absolute superlative is demonstrable, there can be no doubt that John of Salisbury's spirited "Defense of the Trivium" constitutes a classic in the history of educational theory. Furthermore, as a reasoned presentation of the theoretical bases of an educational prospectus which prevailed, and continued to prevail in Western Europe, it no doubt had some influence on the development of modern education and civilization.

As we have said, on its completion in 1r59, the Metalogicon, together with the Policraticus, was sent. to the royal chancellor Thomas Becket, thus assuring its publication and influence. Several manuscript copies of the Metalogicon were subsequently made. These continued to circulate, as originally, in company with the Policraticus. Although not the kind of work that would attract a large public, the Metalogicon was apparently read by intellectual leaders such as Peter of Blois, Peter of Celle, Alexander Neckam, Robert Grosseteste, William of Auvergne, William of Auxerre, Helinand of Froidmont, Vincent of Beauvais, John Waleys, Walter Burley, and Geoffrey Chaucer. ${ }^{53}$

Abiding recognition of the Metalogicon is witnessed by the six separate printed editions through the centuries since Gutenberg and Coster. With augmented interest in the genetic development of education, learning, and thought, John's "Defense of the Trivium" has

${ }^{\infty}$ See Hauréau, op. cit., I, 536; and Clerval, op. cit., p. 230.

${ }^{61}$ For antitheses: Met., iv, 41-42. For figures of speech: Met., i, 18-19. For humor: Met., i, 3; ii, 6, 7 .

${ }^{52}$ Baldwin, op. cit., p. 155 .

${ }^{50} \mathrm{Cf}$. Webb in the Prolegomena to the Policraticus, p. xlviii. For Helinand: H. Hublocher, Helinand von Froidmont und sein Verhältnis zu Johannes von Salisbury. 
come to be one of our most thumbed sources. Many accounts of the history of Western intellectual culture are liberally sprinkled with footnotes referring to the Metalogicon; indeed, some go so far as to quote extensive translated extracts. Representative authorities relying considerably on the Metalogicon include: Friedrich Ueberweg, Heinrich Ritter, Barthélemy Hauréau, François Picavet, Martin Grabmann, Etienne Gilson, Maurice de Wulf, and Karl Prantl in the history of philosophy; James Mark Baldwin and George S. Brett in the history of psychology; and Leon Maitre, Augusta Drane, Jules Alexandre Clerval, Hastings Rashdall, G. Robert, Charles S. Baldwin, Bigerius Thorlacius, Reginald Lane Poole, Bishop William Stubbs, J. E. Sandys, G. Paré, A. Brunet, and P. Tremblay, Eduard Norden, F. A. Wright, Charles Homer Haskins, and T. A. Sinclair in the history of education and learning.

The Metalogicon, reflecting its versatile author, sparkles with many facets. It is important enough to be something of a landmark in several fields of learning, including philosophy, theology, psychology, and education. In philosophy, it is the first known work to urge and provide the blueprint for a widespread study of the whole of Aristotelian logic. ${ }^{54}$ Its convincing arguments for the mastery of the arts relative to deductive and inductive reasoning led naturally, not only into thirteenth-century scholasticism, but also even into modern science. There can be no doubt that modern trends in philosophy and learning are discernible in its frank eclecticism, moderate skepticism, historical approach, and stress on practical applicability. ${ }^{55}$ In theology, its concept of the coöperative relation between faith and reason suggests the maxim of mutual corroboration accepted by thirteenth-century thinkers. In psychology, it is classed as both an early instance of empirical psychology, and a crier heralding the possibilities and future evolution of this science. ${ }^{56}$ In learning it is a golden example of mediaeval familiarity

\footnotetext{
${ }^{54}$ Thus Karl Prantl in Geschichte der Logik..., Bd. II (Vol. I), 233-260, where almost thirty pages are given to a discussion of John of Salisbury.

${ }^{55}$ For eclecticism: Met., Prologue; and iii, Prologue. For moderate skepticism: Met., iv, 3I, 4I. For historical approach: Met., Prologue; i, I-6, II-I4, 24-25; ii, Prologue, I-2, 6, 10, 16-20, passim.

${ }^{56}$ G. S. Brett, A History of Psychology, II, 87, 93, 219-220; and J. M. Baldwin, History of Psychology, I, $86 \mathrm{ff}$., Ioo.
} 
with classical literary lore, as well as of accomplished Latinity. Finally, it is a treasure-trove of information concerning twelfthcentury pedagogy, as well as an enduring classic by its own right in the field of educational theory. 



\title{
I O A N N E S S A R E S BERIENSIS METALOGICVS.
}

\section{$E$ Codice $M$ S. Academia \\ Cantabrigienfis.}

Nunc primum Editus.

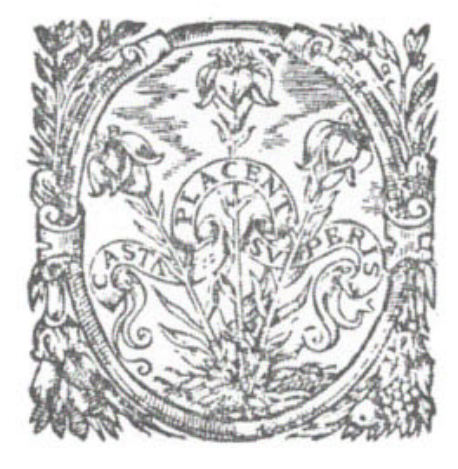

\author{
PARISIIS. \\ Apud Had I a V M BEYs. \\ Viâ Iacobæa. \\ M. DC. X.
}

TITLE PAGE OF THE METALOGICON

First printed edition, Paris, I6ro. 
